\title{
Antibacterial Activity of Austdiol Isolated from Mycoleptodiscus indicus Against Xanthomonas axonopodis pv. passiflorae
}

\author{
de Oliveira, L. C.; ${ }^{*}$ Ishida, A. K. N.; da Silva, C. T. B.; Carvalho, J. M.; \\ Feitosa, A. O.; Marinho, P. S. B.; Marinho, A. M. R.
}

Rev. Virtual Quim., 2019, 11 (3), 596-604. Data de publicação na Web: 15 de abril de 2019

http://rvq.sbq.org.br

\section{Atividade Antibacteriana de Austidiol Isolado de Mycoleptodiscus indicus Contra Xanthomonas axonopodis pv. passiflorae}

Resumo: Doenças de plantas causadas por bactérias resultam em perdas graves para a agricultura. O estudo químico de fungos endofíticos representa uma área em potencial no desenvolvimento de pesticidas biológicos. Assim, o presente trabalho teve como objetivo verificar a atividade antibacteriana do extrato do fungo endofítico Mycoleptodiscus indicus NF12 de Morinda citrifolia contra Xanthomonas axonopodis pv. passiflorae, bactéria causadora da mancha bacteriana do maracujazeiro, bem como, determinar qual composto é responsável pela atividade observada. 0 composto austidiol (1) foi isolado através de métodos cromatográficos do extrato metanólico da biomassa do fungo endofítico $M$. indicus NF12 e apresentou atividade bacteriostática em todas as concentrações testadas sobre cinco isolados de $X$. axonopodis pv. passiflorae.

Palavras-chave: Fungos endofíticos; austidiol; Xanthomonas axonopodis pv. passiflorae.

\begin{abstract}
Plant diseases caused by bacteria result in severe losses to agriculture. The chemical study of endophytic fungi represents a potential area in the development of biological pesticides. Thus, the present work aimed to verify the antibacterial activity of the extract of the endophytic fungus Mycoleptodiscus indicus NF12 from Morinda citrifolia against Xanthomonas axonopodis pv. passiflorae, a bacterium that causes bacterial blight of passion fruit, as well as to determine which compound is responsible for the observed activity. The compound austdiol (1) was isolated by chromatographic methods from the methanolic biomass extract of the endophytic fungus $M$. indicus NF12 and showed bacteriostatic activity at all concentrations tested on five strains of $X$. axonopodis pv. passiflorae.
\end{abstract}

Keywords: Endophytic fungi; austdiol; Xanthomonas axonopodis pv. passiflorae.

\footnotetext{
* Federal University of Pará, Institute of Exact and Natural Sciences, CEP 66075-110, Belém-PA, Brazil. $M$ luanacardoso.oliveira@hotmail.com DOI:10.21577/1984-6835.20190045
} 


\section{Antibacterial Activity of Austdiol Isolated from Mycoleptodiscus indicus Against Xanthomonas axonopodis pv. passiflorae}

Luana C. de Oliveira, ${ }^{\mathrm{a}, *}$ Alessandra Keiko N. Ishida, ${ }^{\mathrm{b}}$ Clenilda Tolentino B. da Silva, ${ }^{\mathrm{b}}$ Josiwander M. Carvalho, ${ }^{\mathrm{a}}$ André de O. Feitosa, ${ }^{\mathrm{a}}$ Patrícia Santana B. Marinho, ${ }^{\text {a Andrey Moacir do R. Marinho }}{ }^{\mathrm{a}}$

${ }^{a}$ Federal University of Pará, Institute of Exact and Natural Sciences, CEP 66075-110, Belém-PA, Brazil.

b Embrapa Amazônia Oriental, Laboratory of Plant Pathology, CEP 66095-093, Belém-PA, Brazil.

* luanacardoso.oliveira@hotmail.com

Recebido em 18 de abril de 2018. Aceito para publicação em 28 de março de 2019

1. Introduction

2. Experimental

2.1. General procedures

2.2. Microorganism

2.3. Culture of Mycoleptodiscus indicus NF 12 in rice and chemical constituent isolation

2.4. Antibacterial assay with the methanolic extract NF12 and compound 1

\section{Results and Discussion}

3.1. Antibacterial activity of the methanolic extract NF12 and compound 1

3.2. Structural elucidation of compound 1

\section{Conclusion}

\section{Introduction}

Bacterial blight is caused by Xanthomonas axonopodis pv. passiflorae (Pereira) Gonçalves \& Rosato and represents one of the main diseases of passion fruit. It was first observed in Brazil, in 1968, in the region of Araraquara, state of São Paulo, ${ }^{1}$ and occurs in all localities where passion fruit is grown, becoming more severe in hotter and more humid regions. ${ }^{2}$ The disease can be found in orchards of the species Passiflora edulis $\mathrm{f}$. flavicarpa, $P$. alata, $P$. cincinata, $P$. nitida, $P$. quadrangularis, $P$. amethystina, $P$. setacea and $P$. edulis f. edulis. ${ }^{3}$ Xanthomonas axonopodis pv. passiflorae is a gram-negative, strict aerobic bacterium, with mucoid, convex, bright, yellow-colored colonies. ${ }^{4}$

Bacterial blight, also known as oily spot, bacterial boll rot or bacteriosis, when affecting passion fruit, presents typical symptoms distinct from other diseases of passion fruit. In the leaves, the pathogen produces small 
water-soaked and translucent lesions, which necrosis, assuming a reddish-brown color, and may also form a chlorotic halo around the spot
(Figure 1). Whereas in the fruits, the spots are large, initially greenish and oily, then brown, generally circular and well delimited. ${ }^{5}$

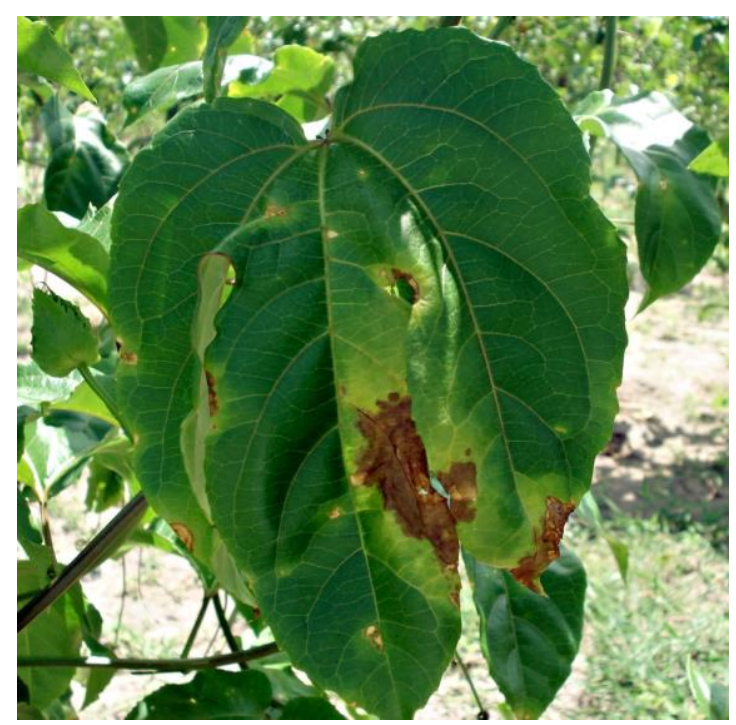

Figure 1. Symptom of bacterial blight in a leaf of passion fruit, caused by Xanthomonas axonopodis pv. passiflorae

Endophytic fungi have been studied in relation to their ability to act as inhibitors of phytopathogenic microorganisms, with the perspective of applying them as biocontrol agents, an alternative to chemical control. Their use can occur directly, in which they are applied alive and act as antagonists; or indirectly, through their metabolites. ${ }^{6,7}$

In previous work, endophytic fungi of Morinda citrifolia were studied and the extracts of some of these fungi showed good antibacterial activity against $X$. axonopodis pv. passiflorae. ${ }^{8}$ Thus, the present study aimed to verify the antibacterial activity of the biomass extract of the endophytic fungus Mycoleptodiscus indicus NF12 from $M$. citrifolia, as well as to determine which compound is responsible by activity observed.

\section{Experimental}

\subsection{General procedures}

Chromatogram and UV spectrum were obtained from Analytical HPLC Waters e2695 equipped with DAD Waters 2998. ESIMS data were acquired in positive and negative ion mode using a Waters Acquity TQD instrument. 1D and 2D NMR spectra were recorded on a Varian Mercury 300, using solvent signal as reference. The chemical shifts are given in delta $(\delta)$ values and the coupling constants $(J)$ in Hertz $(\mathrm{Hz})$.

\subsection{Microorganism}

The endophytic fungus Mycoleptodiscus indicus, code NF12, was obtained from a collection of the Laboratory of Plant Pathology of the Embrapa Amazônia Oriental, Belém-PA, that contains the endophytic fungi isolated from Morinda citrifolia (IAN 188703). 


\subsection{Culture of Mycoleptodiscus indicus NF 12 in rice and chemical constituent isolation}

Two Erlenmeyer flasks (125 mL) containing $30 \mathrm{~g}$ rice (Tio João ${ }^{\circledR}$ ) and $15 \mathrm{~mL}$ distilled water per flask were autoclaved for $45 \mathrm{~min}$ at $121^{\circ} \mathrm{C}$. Small cubes of PDA medium containing mycelium of $M$. indicus NF 12 were added in 01 Erlenmeyer flask under sterile condition, another flask was used as control. After 15 days of growth at $25{ }^{\circ} \mathrm{C}$ the biomass obtained was macerated with methanol. The methanol solution was evaporated under reduced pressure, producing a yellowish residue of the methanolic extract NF12 (103.2 mg). The methanolic extract NF12 was fractionated on a sephadex column using methanol as the mobile phase, from which 16 fractions were obtained, which after analysis by TLC the fractions were pooled from $A 1$ to $A 6$. The fraction A5 was fractionated on ODS column, using water/methanol 20 to $100 \%$ as mobile phase, obtaining 47 fractions, which after analysis by TLC the fractions were pooled from B1 to B10 and of fraction B4 the compound $\mathbf{1}$ was isolated (5 mg).

2.4. Antibacterial assay with the methanolic extract NF12 and compound 1

With the methanolic extract NF12 and compound $\mathbf{1}$, the antibacterial assay was performed at the Laboratory of Plant Pathology of the Embrapa Amazônia Oriental through of the dilution method as recommended by the Subcommittee on Antifungal Susceptibility Testing of the Clinical and Laboratory Standards Institute (CLSI), with modifications. ${ }^{9}$ The assay was performed in 96-well ELISA plates using liquid culture medium $523^{10}$ and 5 strains of $X$. axonopodis pv. passiflorae from the municipalities of Igarapé-Açu (PA 1), Castanhal (PA 4.3), Maracanã (PA 5.2), São Francisco do Pará (PA 18) and Tomé-Açu (PA 20), all in the state of Pará, in the concentrations of $1 \times 10^{8} \mathrm{CFU} \mathrm{mL}$
1. The methanolic extract NF12 and compound 1 were tested at concentrations of 0 ; 3.125; $6.25,12.5 ; 25 ; 50$ and $100 \mu \mathrm{g} \mathrm{mL}$. The experimental design was randomized with 3 replicates and the Elisa plates were incubated for $24 \mathrm{~h}$ at $28{ }^{\circ} \mathrm{C}$. The evaluation was performed by adding $10 \mu \mathrm{L}$ of $2 \%$ TTC $(2,3,5$ triphenyltetrazolium chloride) into each well of the plate. The wells which did not show red color, extract and compound 1, were reinoculated in Petri dishes containing solid culture medium 523 and incubated for $48 \mathrm{~h}$ at $28^{\circ} \mathrm{C}$. Where bacterial growth occurred, it was indicated that the extract and/or compound had bacteriostatic effect at this concentration and where there was no bacterial growth, the extract and/or compound presented bactericidal effect.

\section{Results and Discussion}

3.1. Antibacterial assay with the methanolic extract NF12 and compound 1

The methanolic extract NF12 presented bacteriostatic activity at almost all concentrations on the growth of all strains of $X$. axonopodis pv. passiflorae (Table 1), showing very promising antibacterial activity. Analytical HPLC analysis of the methanolic extract NF12 showed the presence of a major compound at retention time $12.4 \mathrm{~min}$ and maximum absorption at 257 and $377 \mathrm{~nm}$, which is suggestive of a compound of the class of azaphilones (Figure 2). The methanolic extract NF12 was fractionated by chromatographic methods and the compound 1 was isolated, which had its activity tested against the strains of $X$. axonopodis pv. passiflorae, showing to be active at all concentrations tested (Table 1), which showed that compound $\mathbf{1}$ is responsible for the activity verified in the methanolic extract NF12. 
Table 1. Effect of the methanolic extract NF12 and compound 1 from the endophytic fungus Mycoleptodiscus indicus NF12 on the growth of different strains of Xanthomonas axonopodis pv. passiflorae

\begin{tabular}{|c|c|c|c|c|c|c|c|c|}
\hline \multirow{2}{*}{$\begin{array}{l}\text { Strains of } X \text {. } \\
\text { axonopodis pv. } \\
\text { passiflorae }\end{array}$} & \multirow[b]{2}{*}{ Samples } & \multicolumn{7}{|c|}{ Concentrations $\left(\mu \mathrm{g} \mathrm{mL}^{-1}\right)$} \\
\hline & & 0 & 3.125 & 6.25 & 12.5 & 25 & 50 & 100 \\
\hline \multirow{2}{*}{ PA 1} & NF12 & + & - & - & - & - & - & - \\
\hline & $\mathrm{C} 1$ & + & - & - & - & - & - & - \\
\hline \multirow{2}{*}{ PA 4.3} & NF12 & + & + & - & - & - & - & - \\
\hline & $\mathrm{C} 1$ & + & - & - & - & - & - & - \\
\hline \multirow{2}{*}{ PA 5.2} & NF12 & + & + & - & - & - & - & - \\
\hline & C1 & + & - & - & - & - & - & - \\
\hline \multirow{2}{*}{ PA 18} & NF12 & + & - & - & - & - & - & - \\
\hline & $\mathrm{C} 1$ & + & - & - & - & - & - & - \\
\hline \multirow{2}{*}{ PA 20} & NF12 & + & - & - & - & - & - & - \\
\hline & C1 & + & - & - & - & - & - & - \\
\hline
\end{tabular}

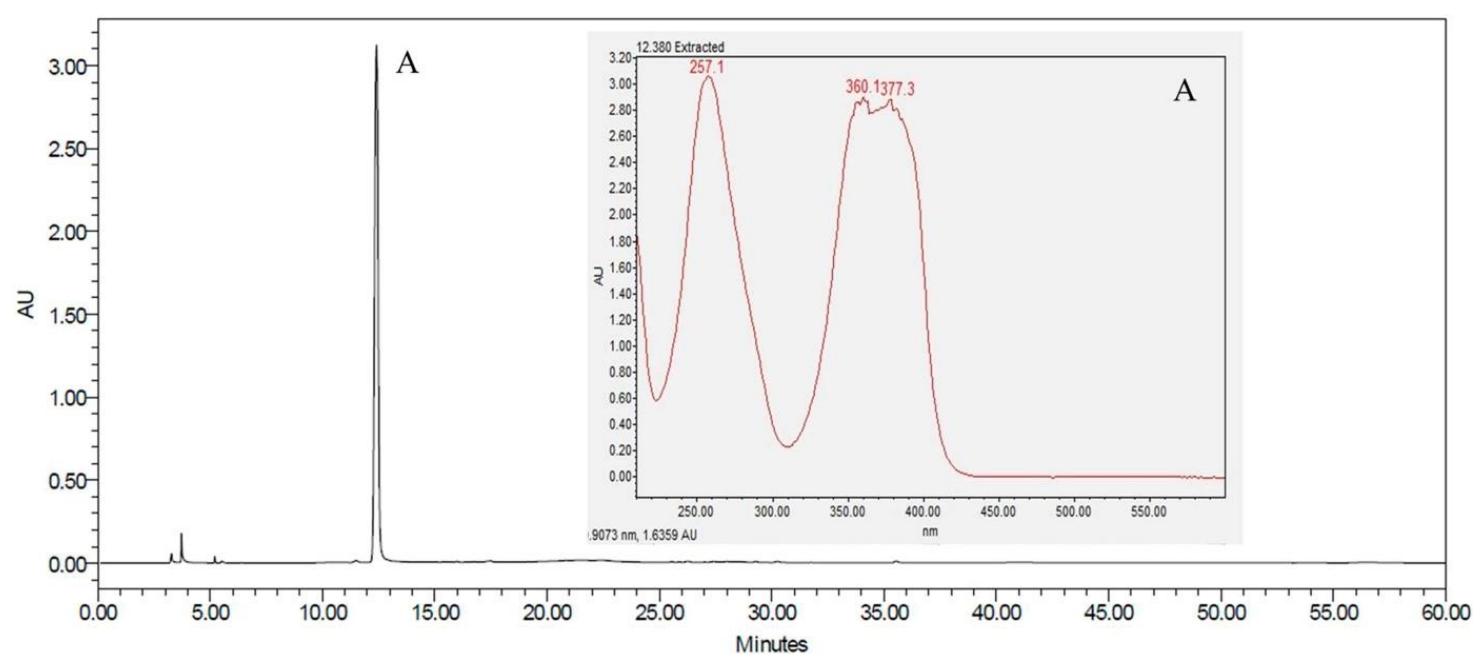

Figure 2. Chromatogram obtained by HPLC-DAD for the extract NF12, $\lambda=254 \mathrm{~nm}$. A - Band with $t_{R}$ of 12.4 min presents UV spectrum with $\lambda_{\max }$ of 257 and $377 \mathrm{~nm}$

3.2. Structural elucidation of compound 1

The compound $\mathbf{1}$ (Figure 3 ) was isolated as a yellow methanol-soluble solid from fraction
B4 of the methanolic extract of the endophytic fungus $M$. indicus NF12. Its structure was elucidated based on its NMR and MS data and comparison with literature data. 


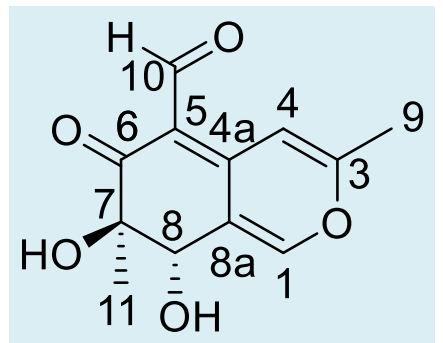

Figure 3. Structure of compound 1

In the ESI(+) mass spectrum of compound 1, ions of $\mathrm{m} / \mathrm{z} 237[\mathrm{M}+\mathrm{H}]^{+}$and $\mathrm{m} / \mathrm{z} 259$ $[\mathrm{M}+\mathrm{Na}]^{+}$were observed, which, together with the NMR data, confirmed the molecular formula $\mathrm{C}_{12} \mathrm{H}_{12} \mathrm{O}_{5}$. In the ${ }^{1} \mathrm{H}$ NMR spectrum, a singlet signal was observed at $\delta_{H} 1.11(3 \mathrm{H}, \mathrm{s}$, $\mathrm{H}-11)$ relative to methyl hydrogens linked to carbinolic carbon, in addition to a singlet signal at $\delta_{\mathrm{H}} 2.45(3 \mathrm{H}, \mathrm{s}, \mathrm{H}-9)$ relative to methyl hydrogens linked to $\mathrm{sp}^{2}$ carbon. Moreover, there was a singlet signal at $\delta_{H} 4.58(s, \mathrm{H}-8)$, attributed to oxymethinic hydrogen, a doublet signal at $\delta_{H} 8.15(1 \mathrm{H}, d, \mathrm{H}-1, J=1.5 \mathrm{~Hz})$, relative to olefinic hydrogen next to the heteroatom and a singlet signal at $\delta_{\mathrm{H}} 8.32(1 \mathrm{H}, \mathrm{s}, \mathrm{H}-4)$, which refers to olefinic hydrogen next to the methyl-linked carbon. Finally, a singlet signal was observed at $\delta_{H} 10.0(1 \mathrm{H}, \mathrm{s}, \mathrm{CHO}-10)$, characteristic of aldehyde hydrogen. In the ${ }^{13} \mathrm{C}$ NMR spectrum, 12 carbon signals were observed, 2 being attributed to methyl carbons $\left(\delta_{c}\right.$ 18.6, C-11; and $\left.\delta_{c} 20.3, \mathrm{C}-9\right), 4$ attributed to non-hydrogenated carbons $\left(\delta_{c}\right.$ 111.5, C-5; $\delta_{c} 125.5$, C-8a; $\delta_{c} 153.3$, C-4a; and $\delta_{c}$ 168.5. C-3), 2 attributed to carbinolic carbons $\left(\delta_{c} 72.4, C-7\right.$; and $\left.\delta_{c} 74.5, C-8\right), 2$ to olefinic carbons $\left(\delta_{c} 108.4, C-4\right.$; and $\delta_{c} 155.5$, C-1), 1 attributed to aldehyde carbonyl carbon $\left(\delta_{c} 191.3, C-10\right)$ and 1 attributed to ketone carbonyl carbon $\left(\delta_{\mathrm{C}} 198.2, \mathrm{C}-6\right)$.

$\mathrm{HMBC}$ correlations of $\mathrm{H}-8$, along with $\mathrm{H}-4$ and Me-11 with carbons C-4a, C-5 and C-6 have evidenced $\alpha, \beta$-unsaturated carbonyl group. Following the HMBC correlations for Me-9 with carbons $\mathrm{C}-3$ and $\mathrm{C}-4$, along with the $\mathrm{HMBC}$ correlations of $\mathrm{H}-1$ with carbons $\mathrm{C}-3$ and $\mathrm{C}-8 \mathrm{a}, \mathrm{a}$ pyran-quinone group was observed. This information showed that compound 1 belongs to the class of azophilones. Finally, the observed $\mathrm{HMBC}$ correlation of $\mathrm{H}-10$ with carbons $\mathrm{C}-5$ and $\mathrm{C}-4 \mathrm{a}$ made it possible to locate the localization of the aldehyde group at C-5.

Data regarding ${ }^{1} \mathrm{H}$ and ${ }^{13} \mathrm{C}$ NMR were compared with the literature (Table 2) and it was concluded that the compound 1 is (7R,8S)-7,8-dihydro-7,8-dihydroxy-3,7-

dimethyl-6-oxo-6H-2-benzopyran-5-

carboxaldehyde, known as austdiol. ${ }^{11}$

Austdiol is an azaphilone isolated for the first time from Aspergillus ustus, a contaminant found in foodstuffs. ${ }^{11}$ Azaphilones are a structurally diverse class of secondary metabolites of fungi (polyketide derivatives), known pigments with a pyranquinone structure containing a highly oxygenated bicyclic nucleus and a quaternary chiral center. ${ }^{12-14}$

Other works present the isolation of austdiol from endophytic fungi, in which it was also isolated from the species $M$. indicus, obtained from leaves of Borreria verticillata. ${ }^{15}$ Furthermore, austdiol was isolated from the endophytic fungus coded as $\mathrm{DgCr} 22.1 \mathrm{~b}$, from the root bark of Duguetia stelechantha, ${ }^{16}$ and from the endophytic fungus coded as CRI7 from Tiliacora triandra. ${ }^{17}$

More than 170 different azaphilones occur in fungi belonging to 23 genera of 13 different families. There have been reports of several biological activities for this class of substances, such as: antimicrobial, antifungal, antioxidant, antiviral, cytotoxic, nematicidal and antiinflammatory activity. ${ }^{18}$ 
Table 2. Data regarding $\mathrm{NMR}{ }^{1} \mathrm{H}$ and ${ }^{13} \mathrm{C}\left(\mathrm{CD}_{3} \mathrm{OD}, 300 \mathrm{MHz}\right)$ of compound 1

\begin{tabular}{ccc}
\hline 1 & ${ }^{1} \mathbf{H}$ & ${ }^{13} \mathbf{C}$ \\
3 & $8.15(d)$ & 155.5 \\
4 & - & 168.5 \\
$4 \underline{a}$ & $8.32(s)$ & 108.4 \\
5 & - & 153.3 \\
6 & - & 111.5 \\
7 & - & 198.2 \\
8 & - & 72.4 \\
$8 \underline{a}$ & $4.58(s)$ & 74.5 \\
$9-\mathrm{CH}_{3}$ & - & 125.5 \\
$10-\mathrm{CHO}^{2}$ & $2.45(s)$ & 20.3 \\
$11-\mathrm{CH}_{3}$ & $10(s)$ & 191.3 \\
\hline
\end{tabular}

Is describe in the literature phytotoxic activity to some azaphilones. ${ }^{19-20}$ This information corroborate with the tendency of natural phytotoxins have been considered hit compounds to development the new herbicides in substitution of the chemical synthetics herbicides. ${ }^{21}$ For example of azaphilones obtained from endophytic fungi with phytotoxic activity able to be cited the azaphilones chaetomugilin D and chaetomugilin $\mathrm{J}$ isolated from Chaetomium globasum, a endophytic from leaves of the Amaranthus viridis. ${ }^{22}$

For the azaphilone austdiol isolated in the present work was described cytotoxic activity against tumor cells and leishmanicidal activity on Leishmania major and L. dovani. ${ }^{15}$ However, there are no studies on its activity against agricultural pests such as the bacterial blight of passion fruit, this being the first report of this important activity for the austdiol, which can open the possibility of production of a new antibacterial agent for the control of $X$. axonopodis pv. passiflorae.

\section{Conclusion}

The methanolic extract of the biomass of the endophytic fungus $M$. indicus NF12 showed good antibacterial activity against $X$. axonopodis pv. passiflorae, a bacterium that causes bacterial blight of passion fruit. The chemical study of the methanolic extract of $M$. indicus NF12 led to the isolation by chromatographic methods of the compound austdiol (1) as the responsible for the observed activity, being active at all concentrations tested. This is the first report of antibacterial activity of the compound austdiol against $X$. axonopodis pv. passiflorae, demonstrating that the chemical study of endophytic fungi is a potential area in the development of new biological pesticides.

\section{Referências Bibliográficas}

${ }^{1}$ Pereira, A. L. G. Uma nova doença bacteriana do maracujá (Passiflora edulis Sims) causada por Xanthomonas passiflorae n. sp. Arquivos Instituto Biológico 1969, 36, 1. [CrossRef] 
2 Junqueira, N. T. V.; Junqueira, K. P. Em Manejo das principais doenças do maracujazeiro; Sussel, A. A. B.; Medeiros, F. H. V.; Ribeiro Júnior, P. M.; Uchoa, C. N.; Amaral, D. R.; Medeiros, F. C. L.; Pereira, R. B.; Santos, J.; Lima, L. M.; Roswalka, L. C., eds.; UFLA: Lavras, 2007.

${ }^{3}$ Junqueira, N. T. V.; Anjos, J. R. N.; Junqueira, L. P.; Sharma, R. D. Em Principais Doenças e Pragas: Doenças do Maracujá-Doce; Manica, I.; Brancher, A.; Sanzonowicz, C.; Icuma, I.M.; Aguiar, J. L. P.; Azevedo, J. A.; Vasconcellos, M. A. S.; Junqueira, N. T. V., eds.; Cinco Continentes: Porto Alegre, 2005.

${ }^{4}$ Halfeld-Vieira, B. A.; Nechet, K. L. Ocorrência da mancha bacteriana do maracujazeiro em Roraima. Fitopatologia Brasileira 2006, 31, 214. [Link]

${ }^{5}$ Viana, F. M. P.; Freire, F. C. O.; Cardoso, J. E.; Vidal, J. C. Principais doenças do maracujazeiro na Região Nordeste e seu controle, Embrapa Agroindústria Tropical: Fortaleza, 2003.

${ }^{6}$ Lazzaretti, E.; Bettiol, W. Tratamento de sementes de arroz, trigo, feijão e soja com um produto formulado à base de células e de metabólitos de Bacillus subtilis. Scientia Agricola 1997, 54, 89. [CrossRef]

7 Grigoletti Junior, A.; dos Santos, A. F.; Auer, C. G. Perspectivas do uso do controle biológico contra doenças florestais. Floresta 2000, 30, 155. [CrossRef]

${ }^{8}$ De Oliveira, L.C. Dissertação de Mestrado, Universidade Federal do Pará, Brasil, 2015. [Link]

${ }^{9} \mathrm{CLSI} ;$ Methods for Dilution and Antimicrobial Susceptibility Tests for Bacteria that Grow Aerobically, 10a. ed., CLSI document M07A10, Wayne: Clinical and Laboratory Standards Institute, 2015.

10 Kado, C. I.; Heskett, M. G. Selective media for isolation of Agrobacterium, Corynebacterium, Erwinia, Pseudomonas and Xanthomonas. Phytopathology 1970, 60, 969. [CrossRef]
${ }^{11}$ Vleggaar, R.; Steyn, P. S.; Nagel, D. W. Constitution and absolute configuration of austdiol, the main toxic metabolite from Aspergillus ustus. Journal of the Chemical Society, Perkin Transactions 1 1974, 1, 45. [CrossRef] [PubMed]

12 Sturdikova, M.; Slugen, D.; Lesova, K.; Rosenberg, M. Mikrobialna produkcia farebnych azafilonovych metabolitov. Chemické Listy 2000, 94, 105. [Link]

13 Zhu, J.; Grigoriadis, N. P.; Lee, J. P.; Porco, J. A. Synthesis of the azaphilones using coppermediated enantioselective oxidative dearomatization. Journal of the American Chemical Society 2005, 127, 9342. [CrossRef] [PubMed]

14 Dong, J.; Zhou, Y.; Li, R.; Zhou, W.; Li, L.; Zhu, Y.; Huang, R.; Zhang, K. New nematicidal azaphilones from the aquatic fungus Pseudohalonectria adversaria YMF1.01019. FEMS Microbiology Letters 2006, 264, 65. [CrossRef] [PubMed]

${ }^{15}$ Andrioli, W. J. Tese de Doutorado, Universidade de São Paulo, Brasil, 2012. [Link]

${ }^{16}$ De Souza, M. P. Dissertação de Mestrado, Universidade Federal do Amazonas, Brasil, 2012. [Link]

17 Senadeera, S. P. D.; Wiyakrutta, S.; Mahidol, C.; Ruchirawat, S.; Kittakoop, P. A novel tricyclic polyketide and its biosynthetic precursor azaphilone derivatives from the endophytic fungus Dothideomycete sp. Organic \& Biomolecular Chemistry 2012, 10, 7220. [CrossRef] [PubMed]

${ }^{18}$ Osmanova, N.; Schultze, W.; Ayoub, N. Azaphilones: a class of fungal metabolites with diverse biological activities. Phytochemistry Reviews 2010, 9, 315. [CrossRef]

${ }^{19}$ Foremska, E.; Kostecki, M.; Chelkowski, J. Biosynthesis, preparation and properties of ascochitine. Engineering in Life Sciences 1992, 12, 461. [CrossRef]

${ }^{20}$ Nakajima, H.; Kimura, Y.; Hamasaki, T. Spiciferinone, an azaphilone phytotoxin produced by the fungus Cochliobolus spicifer. Phytochemistry 1992, 31, 105. [CrossRef] 
${ }^{21}$ Lu, Y.-H.; Li, S.; Shao, M.-W.; Xiao, X.-H; Kong, L.-C.; Jiang, D.-H.; Zhang, Y.-L. Isolation, identification, derivatization and phytotoxic activity of secondary metabolites produced by Cladosporium oxysporum DH14, a locustassociated fungus. Journal of Integrative Agriculture 2016, 15, 832. [CrossRef]
22 Piyasena, K. G. N. P.; Wickramarachchi, W. A. R. T.; Kumar, N. S.; Jayasinghe, L.; Fujimoto, Y. Two phytotoxic azaphilone derivatives from Chaetomium globosum, a fungal endophyte isolated from Amaranthus viridis leaves. Mycology 2015, 6, 158. [CrossRef] 